\title{
パソコンによる人工衛星データを用いた放流水拡散域評価法の提案 \\ Estimation of Effluent Diffusion through Satellite \\ Remote Sensing with Personal Computer
}

\author{
大西外明* ${ }^{*}$ 河合弘泰 ${ }^{* *}$
}

By Sotoaki ONISHI and Hiroyasu KAWAI

\begin{abstract}
A System for the analysis of river effluents using satellite data is developed. Effluents from the Shingu River are analyzed as an example to study the difference in diffusion areas detected by water temperature and water turbidity. When the effluent discharge is small, the turbidity distribution of the river mouth may be affected by the floating substances released from neighboring other rivers. But the water temperarure is not affected significantly by the neighboring rivers. Thus the water temperature distribution is more proper parameter, in comparison with the turbidity distribution, to be employed in field surveys of the effluent diffusion.

Keywords: effluent, temperature, turbidity, remote sensing,
\end{abstract}

\section{1 . 緒言}

各種の排水を負荷された河川水，あるいは沿岸水域へ直接放出された污染水等が，沿岸水域環境に及ぼす 影響を尒湘するためには，現地調查等により当該水域における乱れ拡散等の水理特性を予め把握しておく必 要がある。その際に調查項目に組み入れられる水質関連の指標としては透明度, 濁度, 塩分蕽度, 水温, $\mathrm{B}$ OD, COD等があるが, これらの内で水温と濁度あるいは塩分灌度の镜測は，その海域における放流水の 力学的特性を把握する上で特に重要であると考えられる。そこで, これらを媒介として放流水の拡散特性を 钼測しようとする場合，選定する媒介の如何により特定される拡散域に差異が出ることが予测される。しか し，この点に関して十分に解明されていないのが現状であると考えられる。

その理由として水温胁散域と濁質拡散域との関連を明らかにする為には水域全体にわたるこれらの水質指 標の分布状態を眵時に観测することが望まれるが，このような空間スケールの大きな水理現象を，従来の観 測法によって瞬間的に锤察することが不可能である事が挙げられる。その点，人工衛星りモートセンシング によれば，例えば本論文で用いたランドサットによれば，110km $\times 110 \mathrm{~km}$ 程度の水域を一度に観察することが でき，さらに同一地点での現象を過去に朝って解析することが出来るという利点もある。しかし，水理学へ

* 正会員 工博 東京理科大学教授 理工学部土木工学科

（广278千葉県野田市山崎2841）

** 学生会員 東京理科大学大学院 理工学部土木工学科

（テ278千葉県野田市山崎2641） 
の人工衛星リモートセンシング利用に関する従来の研究 ${ }^{122)}$ は流れ分布の画像化--可視化一ーに重点が置かれ ており，そこで得られた結果は水理現象を感覚的あるいは定性的に捉えるためには有用であるものの，定量 的把握のためには甚だ不満足な域に留まっていると考えられる。

以上の事を考感して，本論文では沿岸水域における放流水調查時の媒介選定が拡散域評価に及ほす影響を 明らかにする観点から，人工街星データを数值的に解析するプログラムを構築し，新宮川（熊野川）河口沖 を例として解析を行なつた。尚，この解析は従来の様に大型コンピューターは用いず，近年のパーソナル・ コンピューターの技術進歩と普及を踏まえNEC PC-9801 クラスのバーソナル・コンピューターを用いて行な うこととした。

\section{2 . 解析に用いた人工衛星数值テータ}

$2 \cdot 1$ ランドサット・データ

本研究ではデータ量が最も多く解像度の高いランドサット・データを用いて検討を行なう。ランドサット はTM (Thematic Mapper)と呼ばれるセンサによって地表の探查を行なっている。TMによって得られるデ 一夕は表-1に示すband 1〜band 7の波長帯に分割された形で一般に提供されている。

\section{$2 \cdot 2$ 放流水の影签籍囲を算定する媒介}

可視光データ (TM-band 1〜band 3)の水面耀度（以後 CCT値と呼ぶ）は水域の色合いに関保するものである。 そして,この水の色合いは濁度, 水中浮遊物質の色, 塩分䠝度等, 多くの物理的, 化学的要素に支配されて いる。しかし，本論文においては検討対象を洪水時の濁つた河川放流水としているため，主として濁度によ つて支配されているものと見なすことができる゙)。一方, 熱赤外データ(TM-band6)の CCT值は, 水面温度に 依存している。従って, TM-band 2 (TM-band 1,3 でも可) の CCT值の分布とTM-band 6 の CCT值の分布を 比較することにより，沿岸放流水の搪散域を濁度によって評価する場合と水温による場合との差異を定量的 に知ることができる。

\section{3.人工街星データによる放流水流軸の算定}

\section{$3 \cdot 1$ 放流水流軸に関する仮定}

厳密には自然界での噴流やプリュームは空間的に見て三次元的現象であり，その流軸を正確に剆定するこ とは容易でない。また，速度分布，物質濃度分布，温度分布の何れに基づくかにより，その流軸に差異が生 ビるものと尔想される。本論文においては，放流水の海域での挙動を二次元的なものとして扱えるものと仮 定する。この仮定の下では放流水流軸は流れの断面内で CCT值が最大となる点を連ねた線となる。例えば， TM-band 2 のデータからは物質蕽度（濁度）の流軸を求めることができる。

\section{$3 \cdot 2$ 拡教域の抽出}

写真-1(a), (b) は新宮川河口沖合いの1988年 9月26日のランドサットTM-band 2 及びband 6の画像である。

表-1 TMのband

\begin{tabular}{|c|c|c|c|}
\hline band & 波長帯域 $\mu \mathrm{m}$ & 色 光 名 & 分解能 \\
\hline 1 & $0.45 \sim 0.52$ & 可視・青色 & \multirow{5}{*}{$30(\mathrm{~m})$} \\
\hline 2 & $0.52 \sim 0.60$ & 可視 - 綠色 & \\
\hline 3 & $0.63 \sim 0.69$ & 可視 - 赤色 & \\
\hline 4 & $0.76 \sim 0.90$ & 近赤外線 & \\
\hline 5 & $1.55 \sim 1.75$ & 中間赤外線 & \\
\hline 6 & $10.4 \sim 12.5$ & 遠赤外線 & 120 (m) \\
\hline 7 & $2.08 \sim 2.35$ & 中間赤外線 & $30(\mathrm{~m})$ \\
\hline
\end{tabular}

地図-1 新宮川河口付近地図

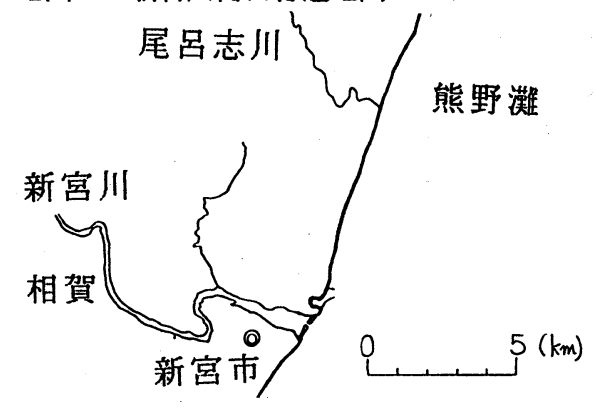


この日に先立つ9月24日, 同河川流域には最大時間降雨量 225吅の降雨があり, 当26日朝 9時の相賀（河口 から約10kn上流）地点における河川流量は $1,150\left(\mathrm{a}^{\mathrm{3}} / \mathrm{s}\right)$ であった。新宮川河口の北北東方向約 $8(\mathrm{kn})$ には尾 呂志川が開口しているが，この日の新宮川からの放淔水は尾吕志川の影響を受けていない。次に写真-2(a)，

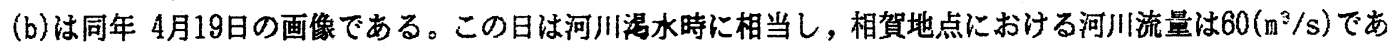
つた。新宮川河口以北の沿岸流や尾呂志川放流水の影䨟が新宮川河口沖にまで達していることが明確である。 この様な場合には，注目する放流水の拡散域のみを抽出しなくてはならない。

そこでまず，新宮川河口付近のシュード処理画像(512 Pixels 400 Lines）を画面に表示させ，新宮川の 河川放流水の㹡散域が入るような長方形項域（M Pixels×N Lines）を切り出す。このとき, 尾吕志川等他 の河川の拡散域が極力入らないようにする。流軸の計算はこの長方形領域内のデータを用いて行なえば良い が，全データを解析に用いると長い計算時間を要することから4 Pixels, 8 Pixelsなど適当な間隔にデータ を間引いて図-1に示すような横 $\mathrm{m}$ 個 $\times$ 縦 $\mathrm{n}$ 個のメッシュ・データで計算する。

\section{$3 \cdot 3$ 流軸の算定方法}

本論文では流軸の定義を「CCT值を重みとし最小自乗法によって回帰した曲線」と定める。この流軸がど のような種類の曲線であるか定かではないが，式(1)に示す放物線を仮定する。

$$
L=a_{0}+a_{1} P+a_{2} P^{2}
$$

ここに, $a_{0}, a_{1}, a_{2}$ は回帰倸数である。问， $a_{0}$ に河口のL (Line)座漂を与えて棌数 $a_{1}, a_{\varepsilon}$ を求める方法 も考えられるが，敢えてa。を变数として取り扱い自由度の高い回帰計算をした方が良好な結果を得ること が多い。その場合，回帰曲線は河口から若干ずれた所を通る曲線となるが，流れの全体的な㑯向をよく㨡ん だ曲線となる。偏差（残差） $\delta \mathrm{k}$ は次式で表される。

$$
\delta_{\mathrm{K}}=\mathrm{L}_{\mathrm{K}}-\left(\mathrm{a}_{0}+\mathrm{a}_{1} \mathrm{P}_{\mathrm{K}}+\mathrm{a}_{2} \mathrm{P}_{\mathrm{K}}{ }^{2}\right)
$$

ここに添光字 $\mathrm{k}$ は,メッシュ・データの左上から右下まで順に付けた要素番号である。

ここで, 各要素に付す重みW $\mathrm{W}_{\mathrm{K}}$ を以下のようにして導入する。

ランドサットのTMのデータは各band毎にそれぞれ Oから 255までの CCT値になつている。この内可視領 域のバンドでは一般に陸地の CCT值は水域の CCT值よりも遥かに大きく，水域においては河口における CCT 值が最も大きく，沖合いに行くにつれて希积湿合が進み，CCT值は小さな值となる。従つて，メッシュ・デ 一タの各要素の CCT值 $\mathrm{U}_{\mathrm{k}}$ に対応した重みW $\mathrm{k}$ を用いて陸地を水域から分離することを考えると， $\mathrm{U}_{\mathrm{m}: \mathrm{n}}$ を 河口における CCT値として，式(3) に示す条件が必要である。

写真-1 1988年9月26日

(a) TM-band 2

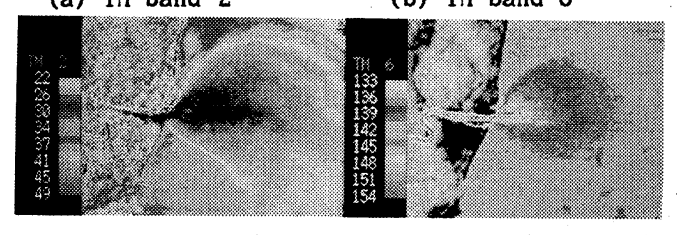

写真-2 1988年4月19日

(a) TM-band 2

(b) TM-band 6

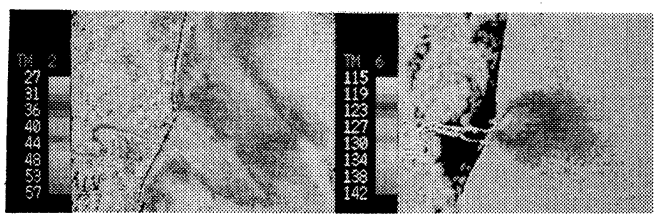

図-1 メッシュ・データの作製

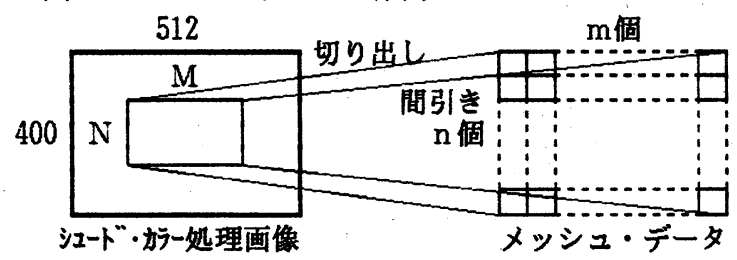

図-2 流軸の回㷌

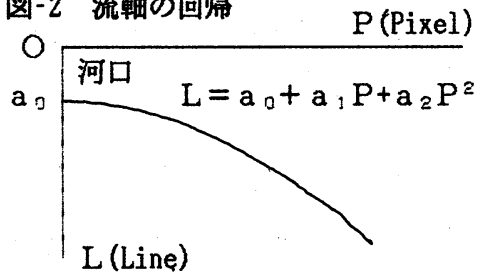




$$
W_{k}=0 \quad\left(U_{M+h}<U_{k}\right)
$$

次に，他河川の放流水（尾吕志川など）や沿岸流の影蔀分を除くため，その最大CCT值をU の条件も必要である。

$$
W_{k}=0 \quad\left(U_{k} \leqq U_{s h}\right)
$$

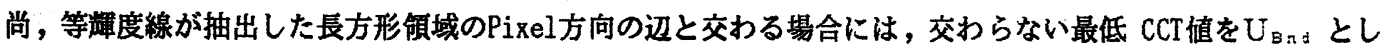
て式(5) の条件も必要である。これは当該河川の拡散域を長方形領域として抽出したとき，拡散領域がこの 境界によって切断された影䱥を除くためである。

$$
\mathrm{W}_{\mathrm{k}}=0 \quad\left(\mathrm{U}_{\mathrm{k}}<\mathrm{U}_{\mathrm{B} \mathrm{n}}\right)
$$

以上の操作によって, 陸域や他河川の拡散域を除去できた（図-3(c))。最後に，当該河川の拡散域について C C T值が大きくなるにつれて重みW $\mathrm{x}$ が大きくなるように定めると，結局，重みW $\mathrm{x}$ は次の様に定義できる。

$$
\begin{array}{ll}
W_{k}=0 & \left(U_{k}<U_{B n d}, U_{M t h}<U_{k}\right) \\
W_{k}=U_{k}-U_{B_{n} d} & \left(U_{B_{n}} \leqq U_{k} \leqq U_{M+h}\right) .
\end{array}
$$

水温の流軸もTM-band 6 を用いて同粎に求める事ができる。ただし，季節によっては；河口での CCT値が 小さく（水温が低く），沖に向かって CCT値が高く（水温が高く）なる場合がある。その場合には式(6)の 代わりに式(7) の重みW $\mathrm{K}$ を用いる。

$$
\begin{array}{ll}
W_{k}=0 & \left(U_{k}<U_{M t h}, U_{B n}<U_{k}\right) \\
W_{k}=U_{B n t}-U_{k} & \left(U_{M t h} \leqq U_{k} \leqq U_{B_{n d}}\right)
\end{array}
$$

以上の様にして定めた重み $\mathrm{W}_{\mathrm{K}}$ と式(2) より，偏差 2 乗和 $\mathrm{S}$ は次式で表される。

$$
\mathrm{S}=\Sigma \mathrm{W}_{\mathrm{K}} \delta_{\mathrm{K}}{ }^{2}=\sum \mathrm{W}_{\mathrm{K}}\left\{\mathrm{L}_{\mathrm{K}}-\left(\mathrm{a}_{0}+\mathrm{a}_{1} \mathrm{P}_{\mathrm{K}}+\mathrm{a}_{2} \mathrm{P}_{\mathrm{K}}{ }^{2}\right)\right\}^{2}
$$

この偏差 2 乗和 $\mathrm{S}$ が最小になる条件は，

$$
\frac{\partial \mathrm{S}}{\partial \mathrm{a}_{0}}=\frac{\partial \mathrm{S}}{\partial \mathrm{a}_{1}}=\frac{\partial \mathrm{S}}{\partial \mathrm{a}_{2}}=0
$$

である。この条件をもとに式(8) を計算し，整理すると以下の正規方程式に帰着する。

$$
\Sigma\left(\begin{array}{l}
W_{K} L_{K} \\
W_{K} P_{K} L_{K} \\
W_{K} P_{K}{ }^{2} L_{K}
\end{array}\right]=\Sigma\left(\begin{array}{lll}
W_{K} & W_{K} P_{K} & W_{K} P_{K}{ }^{2} \\
W_{K} P_{K} & W_{K} P_{K}{ }^{2} & W_{K} P_{K}{ }^{3} \\
W_{K} P_{K}{ }^{2} & W_{K} P_{K}{ }^{3} & W_{K} P_{K}{ }^{4}
\end{array}\right]\left[\begin{array}{l}
a_{0} \\
a_{1} \\
a_{2}
\end{array}\right]
$$

この正規方程式を解くことにより，回帰係数 $\mathrm{a}_{0}, \mathrm{a}_{1}, \mathrm{a}_{2}$ が定まる。

図-3(a) 解説図

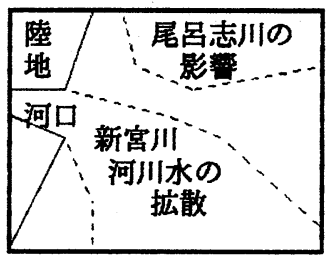

図-3(b) 元データ

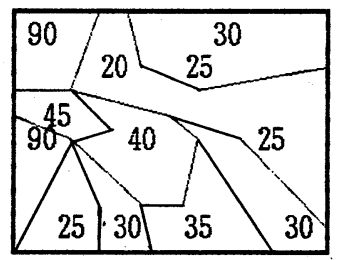

図-3(c) 他河川等の除去 図-3(d) 重み $W_{k}$
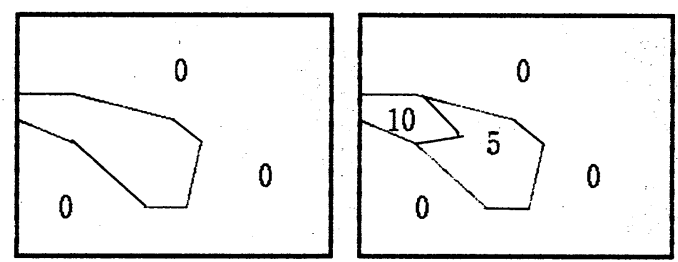
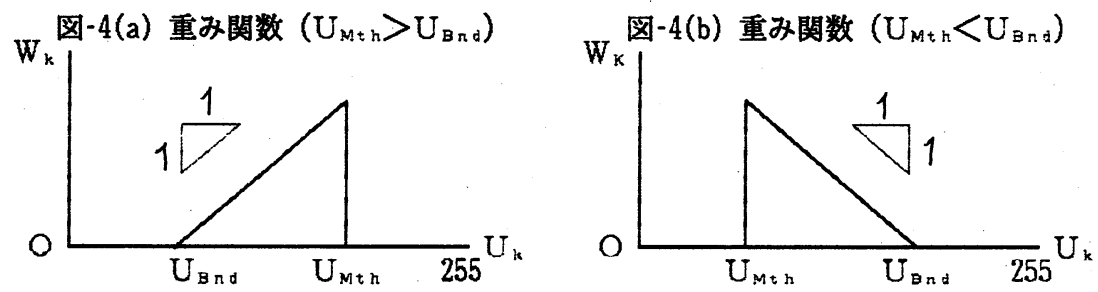


\section{CCT値分布図を描く方法}

図-1のメッシュの任意の格子に注目し，その4つの節点に図-5(a) の様に番号 (1)〜(4)をつけ，その点での CCT 值を $U_{1}, U_{2}, U_{3}, U_{4}$ とする。 $U_{2}$ と $U_{3}$ を比较して $U_{2} \neq U_{3}$ の時には，点(2)点(3)を結ぶ対角線と交 差して等C C T值線を引くことができる。この例では CCT值＝25の等值線が対角線と交差するはずである。こ のCCTの等值線は边(1)-(2)边(1)-(3)の何れかと, 辺2)-(4)か辺(3)-(4)の何机かの 2 箇所で交差する。その 内のどちらに交点が生じるかを $U_{1}, U_{2}, U_{3}, U_{4}$ と等 CCT值の値 $U_{w}=25$ の 5 個の数值の大小関係で判定で きる。図-5(b) の例では，

$$
\left(U_{w}-U_{1}\right)\left(U_{w}-U_{2}\right)<0,\left(U_{w}-U_{1}\right)\left(U_{w}-U_{3}\right)>0
$$

であるから，辺(1)-(2)上に交点があり，

$$
\left(U_{w}-U_{2}\right)\left(U_{w}-U_{4}\right)<0,\left(U_{w}-U_{3}\right)\left(U_{w}-U_{4}\right)>0
$$

であるから，辺( (2)-(4)上に別の交点があることが分かる。この 2 交点を結べば等 CCT值線が得られる。同様 の事を対角線(1)－(4)についても行なつたのが図5-(c) である。以上の操作を全格子について絽り返すことに より等C CT値分布図（CＣT値コンターマップ）が得られる。

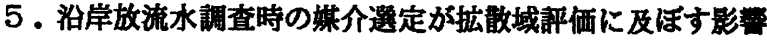

写真-1(a)，(b) 及び写真-2(a)，(b) について，CCT値平面分布を求めた結果を図-6(a),(b) 及び図-7(a)， （b）に示す。図中には前で述べた方法によって求めた流軸線も併記されている。これらの図から，TM-band 2(濁度) とTM-band 6(水温) の流朝および等 CCT值の水平分布は必ずしも一致しないことが明らかである。 放流量が少ない時（図-7(a)，(b))において，その差が特に䫓著である。また，濁度分布は他の河川からの浮 遊砂の影瑯を受けるが, 水温分布の方は殆ど受けないことも分かる。以上のことから考えて, 特定の放流水 の拡散域を調查する場合には，水温を媒介として調查を行なう方が良いことが分かる。

また, 上記の様なband間の相違を定量的に把握する為に，河口から CCT值がほぼ一定となる点までの距離 を各锶测日のband 2とband 6について求めた。両者の距離の差は, 河川水と周囲の水との水温差や濁度差が， 拡散によつて消滅するのに要する距離の差に相当する。図-8は1988年 9月26日の流軸上の CCT值変化を示し たものであるが, band 6の方が河口近くで周囲の水に同化している。また，表-2に他の钼测日の值を含めて

図-5(a)

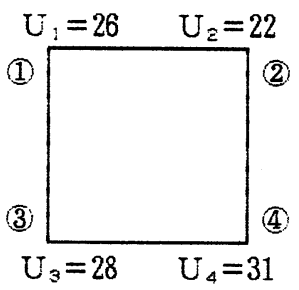

図-5(b)

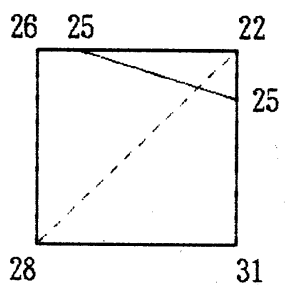

図-5(c)

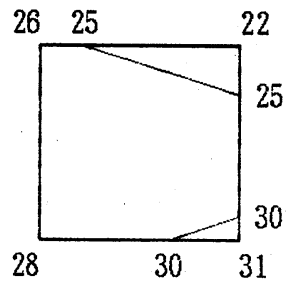

図-6 1988年9月26日の平面的分布

(a) TM-band 2

(b) TM-band 6

図-7 1988年4月19日の平面的分布

(a) TM-band 2

(b) TM-bnad 6
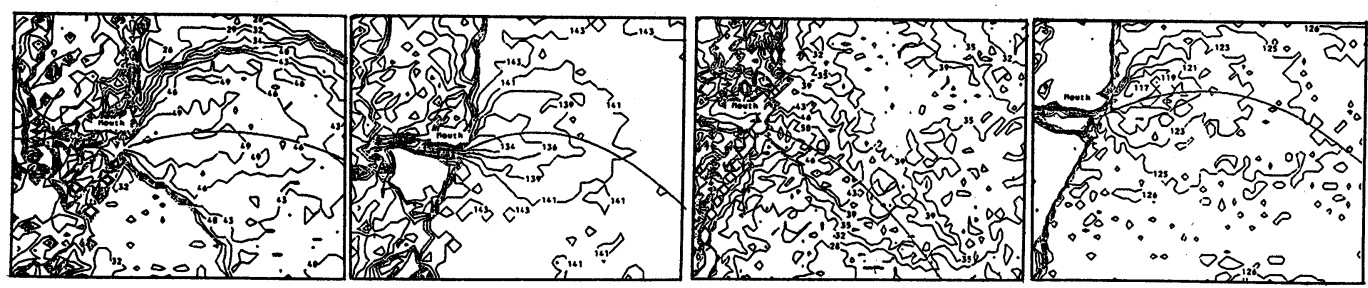
TM-band 2 とband 6の比較を示すが, 河口流量が大きく他河川の影䭗を受けていない日に関しては水温の方 が早く周囲の水に等しくなる㑯向がある。水温の埸合, 水面での熟収支がある為に濁度よりも狭い水域内で 周囲の水に同化していく事は従来から定性的には指揞されて来ているが，本論文で提案した解析によれば表 ー2に記した様にそれを定量的に評価し得る。

尚，図-8中の相対輝度（相対 CCT値）とは，各bandについて「河口において1，十分沖で希釈された所に おいて0」となるように CCT值を換算した無次元量であり，式(13)によって求められる。

$$
U_{R B L}=\left(U_{K}-U_{O f t}\right) /\left(U_{M+h}-U_{O+f}\right)
$$

ここに $U_{K}, U_{M t h}, M_{O+f}$ は任意の位置, 河口, 十分神における絶対輝度 (CCT値)， $U_{R E L}$ はその位置における 相対輝度である4)。

\section{6. 結語}

人工衛星データを用いて，放流水拡散域を数值的に解析する方法を提案した。その適用例として新宮川河 口沖の解析を行なつた。その結果，水温と潈度より評価される放流水拡散域は一致せず，特に，放流水の流 量が少ない時にその差が大きくなることを定量的に示し，また，放流水拡散域の調査には水温の方が道して いる事を指摘した。なお，本論文にて構築した解析プログラムは，単に放流水拡散の解析のみでなく，他の 水理現象を人工衛星データにより解明するためにも適用できる。

本研究は，1990年度文部科学研究「閉鎖性内湾における密度流見象に関する研究」(代表者：室田明）によ り行なわれたことを付記する。

図-8 流軸上のCCT值変化(1988年9月26日)

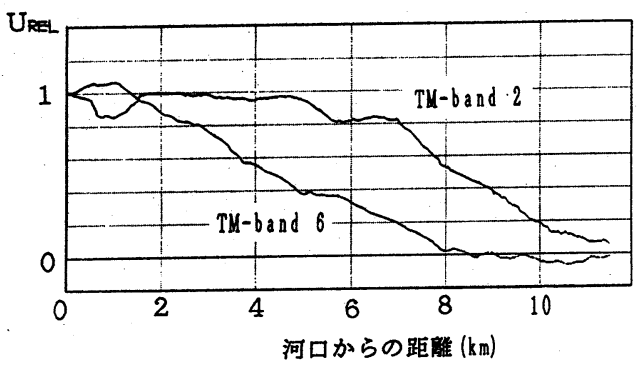

表-2 CCT値が一定となる点までの

距離 (温度と濁度の拡散距離)

\begin{tabular}{|c|c|c|c|}
\hline 付 & Band 2 & Band 6 & 流量 \\
\hline 1988.04 .19 & $3.0 \mathrm{~km}$ & $6.8 \mathrm{~km}$ & 小 \\
\hline 1988.06 .06 & 14.6 & 4.0 & 大 \\
\hline 1988.09 .26 & 10.7 & 8.3 & 大 \\
\hline 1989.05 .08 & 5.2 & 15.4 & 小 \\
\hline 1989.08 .28 & 14.6 & 8.8 & 太 \\
\hline
\end{tabular}

\section{参考文献}

1) Onishi,S. : Roles of Large Scale Eddies in Mass Exchange between Coàstal and Oceanic Zones, Physics of Shallow Estuaries and Bays edited by J. van de Kreeke (Springer-Verlag), pp.168 177, 1984.

2) 大西外明・西村 司：リモートセンシングによる河口㹡散調查と密度流論的検討，土木学会論文報告集， 第289号, pp.75 87, 1979 .

3) 宇田高明・古川博一・竹濎 勉 : ランドサットによる沿岸水理の银測, 第32回海岸工学講演論文集, pp.772 776, 1985 .

4) 田中修三 : ランドサットデータによる河口流出の解析,パソコンによるリモートセンシングデータ解析, 日本リモートセンシング学会出版委員会, pp.164 171. 